\title{
GAMBARAN KEBUTUHAN PERAWATAN PERIODONTAL PADA PEROKOK DI DESA MATUNGKAS KECAMATAN DIMEMBE
}

\author{
${ }^{1}$ Debby J. Suhanda \\ ${ }^{2}$ Damajanty H. C. Pangemanan \\ ${ }^{3}$ Juliatri \\ ${ }^{1}$ Kandidat Skripsi Program Studi Pendidikan Dokter Gigi Fakultas Kedokteran \\ ${ }^{2}$ Bagian Fisiologi Fakultas Kedokteran \\ ${ }^{3}$ Program Studi Pendidikan Dokter Gigi Fakultas Kedokteran \\ Univeristas Sam Ratulangi Manado \\ E-mail: jessicadebbys@gmail.com
}

\begin{abstract}
Periodontal disease is the most common oral disease in Indonesia, especially in rural areas. One of the habits that can aggravate the status of oral hygiene which result periodontal disease is smoking. In addition, the prevalence of smokers in North Sulawesi is quite high when compared to other provinces. This research was conducted in Matungkas Village because high levels of smoking habits. Theres no limit of gender and age for people to smoke, men or women, and teens to the elderly. The purpose of this study was to describe the periodontal treatment needs of the smokers in Matungkas Village District of Dimembe. This type of research is a descriptive research with cross sectional study. The number of samples were taken using the Slovin formula and proportional simple random sampling method. The number of samples are 89 people from 11 parts of the village. Community Periodontal Index Treatment Needs (CPITN) assessment scores was used in this study. The results of this study indicate that the most treatment needs of smokers in the Matungkas Village District of Dimembe seen from the number of cigarettes and frequency of smoking habit is type II services with treatment needs of improvement OHIS and scaling. According to the result, it is suggested that the people of Matungkas village should reduce their smoking habit as a causing factor of periodontal disease and do the routine check up to the dentist every 6 months for the periodontal treatment needed..
\end{abstract}

Keywords: periodontal treatment needs, smokers

\begin{abstract}
Abstrak: Penyakit periodontal merupakan penyakit gigi dan mulut yang paling banyak diderita masyarakat Indonesia, khususnya di daerah pedesaan. Salah satu kebiasaan yang dapat memperburuk status kebersihan mulut dan mengakibatkan terjadinya penyakit periodontal yaitu merokok. Selain itu, prevalensi perokok di Sulawesi Utara cukup tinggi jika dibandingkan dengan provinsi lain. Penelitian ini dilakukan di Desa Matungkas karena tingkat kebiasaan merokok yang tinggi. Jenis kelamin dan usia tidak membatasi masyarakat untuk merokok, laki-laki maupun perempuan, serta usia remaja sampai lanjut usia. Tujuan penelitian ini ialah untuk mengetahui gambaran kebutuhan perawatan periodontal pada perokok di Desa Matungkas Kecamatan Dimembe. Jenis penelitian ini merupakan penelitian deskriptif dengan pendekatan cross sectional study. Besar sampel diambil menggunakan rumus Slovin dan metode proportional simple random sampling. Jumlah sampel yang diambil sebanyak 89 orang dari 11 dusun. Penelitian ini menggunakan skor penilaian Community Periodontal Index Treatment Needs (CPITN). Hasil penelitian ini menunjukkan bahwa gambaran kebutuhan perawatan pada perokok di Desa Matungkas Kecamatan Dimembe dilihat dari jumlah rokok dan lama merokok yang paling banyak ditemukan ialah tipe pelayanan II dengan kebutuhan perawatan perbaikan OHIS disertai skeling. Berdasarkan hasil tersebut, masyarakat perlu mengurangi kebiasaan merokok yang merupakan salah satu faktor penyebab penyakit periodontal dan melakukan pemeriksaan rutin ke dokter gigi setiap 6 bulan sekali untuk mendapatkan perawatan periodontal yang dibutuhkan..
\end{abstract}

Kata kunci: kebutuhan perawatan periodontal, perokok 
Penyakit periodontal merupakan salah satu penyakit yang paling umum terjadi pada individu dewasa. Penyakit ini menempati urutan kedua setelah karies gigi sebagai penyebab kehilangan gigi pada orang dewasa di negara-negara berkembang. Perkembangan penyakit periodontal termasuk lambat dan apabila tidak dirawat dapat menyebabkan kehilangan gigi, namun studi epidemiologi menunjukkan bahwa penyakit ini dapat dicegah dengan menyikat gigi secara teratur dan perawatan skeling. ${ }^{1}$

Perawatan skeling dilakukan untuk menghilangkan plak dan deposit gigi. Setelah perawatan skeling dilakukan dapat terjadi proses penyembuhan berupa hilangnya inflamasi pada jaringan ikat gingiva dan terbentuknya long junctional epithelium. Selain itu, dapat dilakukan perawatan periodontal yang lebih kompleks seperti penyerutan akar menggunakan anestesi lokal dengan atau tanpa prosedur bedah. $^{2}$

Prevalensi penyakit periodontal di Asia dan Afrika lebih tinggi dibandingkan dengan Eropa, Amerika, dan Australia. ${ }^{2}$ Di Indonesia, penyakit periodontal merupakan penyakit gigi dan mulut yang paling banyak diderita masyarakat (70\%) dan lebih banyak di pedesaan daripada perkotaan. Sebesar 4-5\% penduduk menderita penyakit periodontal periode lanjut yang dapat menyebabkan gigi goyang dan tanggal. ${ }^{3}$

Merokok merupakan salah satu kebiasaan yang memperburuk status kebersihan mulut dan dapat menyebabkan terjadinya gingivitis dan periodontitis. Akumulasi plak dalam rongga mulut perokok lebih besar daripada yang bukan perokok. Selain itu, perokok juga lebih mudah mengalami gingivitis daripada orang yang tidak merokok. ${ }^{4}$

Berdasarkan survei World Health Organization (WHO) pada tahun 2009, prevalensi perokok yang berusia $\geq 15$ tahun di dunia sebanyak $36 \%$ pria dan $8 \%$ wanita, dan di Asia Tenggara sebanyak $33 \%$ pria dan $4 \%$ wanita. ${ }^{5}$ Menurut profil Negara Indonesia dalam WHO Report on the Global Tobacco Epidemic tahun 2013, prevalensi perokok di Indonesia usia 15 tahun ke atas sebanyak 34,8\% dan Riset Kesehatan Dasar tahun 2007 menunjukkan di Sulawesi Utara terdapat sebanyak 30,3\% perokok dengan rerata jumlah rokok 11,9 batang per hari. ${ }^{6,7}$

Penelitian ini dilakukan di Desa Matungkas Kecamatan Dimembe. Berdasarkan survei awal masyarakat Desa Matungkas memiliki tingkat kebiasaan merokok yang tinggi. Jenis kelamin dan usia tidak membatasi masyarakat untuk merokok, laki-laki maupun perempuan, serta usia remaja sampai lanjut usia.

Berdasarkan uraian di atas, maka penulis tertarik untuk melakukan penelitian Gambaran Kebutuhan Perawatan Periodontal pada Perokok di Desa Matungkas Kecamatan Dimembe.

\section{BAHAN DAN METODE PENELITIAN}

Penelitian ini merupakan penelitian deskriptif dengan pendekatan cross sectional study yang dilaksanakan pada 1030 September 2014 di Desa Matungkas, Kecamatan Dimembe, Minahasa Utara, Sulawesi Utara. Sampel dalam penelitian ini yaitu masyarakat perokok di Desa Matungkas Kecamatan Dimembe yang berjumlah 89 orang yang diambil dengan metode proportional simple random sampling. Alat dan bahan yang digunakan yaitu sarung tangan, masker, alat diagnostik, probe periodontal, Nierbeken, alat tulis, alkohol 70\%, kapas, antiseptik, desinfektan, kuesioner, formulir pemeriksaan, dan informed consent.

\section{HASIL PENELITIAN}

Data mengenai status periodontal dan kebutuhan perawatan dapat dilihat pada tabel 1 sampai tabel 6 . 
Jurnal e-GiGi (eG), Volume 3, Nomor 1, Januari-Juni 2015

Tabel 1. Distribusi status periodontal berdasarkan skor CPITN

\begin{tabular}{clcc}
\hline Skor CPITN & \multicolumn{1}{c}{ Status Periodontal } & $\mathrm{n}$ & $\%$ \\
\hline 0 & Sehat & 0 & 0 \\
1 & Perdarahan setelah probing & 0 & 0 \\
2 & Kalkulus & 8 & 8,99 \\
3 & Poket patologis 4-5,5mm & 45 & 50,56 \\
4 & Poket patologis $\geq 6 \mathrm{~mm}$ & 36 & 40,45 \\
Total & & 89 & 100,00 \\
\hline
\end{tabular}

Tabel 2. Distribusi kategori perawatan subjek penelitian

\begin{tabular}{clcc}
\hline Tipe Pelayanan & Kategori Perawatan & $\mathrm{n}$ & $\%$ \\
\hline 0 & Tidak ada perawatan & 0 & 0 \\
I & Perbaikan OHIS & 0 & 0 \\
II & Kategori I + skeling & 53 & 59,55 \\
III & Kategori II + perawatan periodontal & 36 & 40,45 \\
Total & kompleks & 89 & 100,00 \\
\hline
\end{tabular}

Tabel 3. Distribusi status periodontal berdasarkan jumlah rokok

\begin{tabular}{|c|c|c|c|c|c|c|c|c|}
\hline \multirow{3}{*}{$\begin{array}{l}\text { Skor } \\
\text { CPITN }\end{array}$} & \multicolumn{6}{|c|}{ Jumlah rokok (batang/hari) } & \multirow{2}{*}{\multicolumn{2}{|c|}{ Total }} \\
\hline & \multicolumn{2}{|c|}{$<10$} & \multicolumn{2}{|c|}{$10-20$} & \multicolumn{2}{|c|}{$>20$} & & \\
\hline & $\mathrm{n}$ & $\%$ & $\mathrm{n}$ & $\%$ & $\mathrm{n}$ & $\%$ & $\mathrm{n}$ & $\%$ \\
\hline 0 & 0 & 0 & 0 & 0 & 0 & 0 & 0 & 0 \\
\hline 1 & 0 & 0 & 0 & 0 & 0 & 0 & 0 & 0 \\
\hline 2 & 4 & 4,50 & 2 & 2,25 & 2 & 2,25 & 8 & 8,99 \\
\hline 3 & 1 & 1,12 & 31 & 34,83 & 13 & 14,60 & 45 & 50,56 \\
\hline 4 & 2 & 2,25 & 19 & 21.35 & 15 & 16,85 & 36 & 40,45 \\
\hline Total & 7 & 7,87 & 52 & 58,43 & 30 & 33,70 & 89 & 100,00 \\
\hline
\end{tabular}

Tabel 4. Distribusi status periodontal berdasarkan lama merokok

\begin{tabular}{|c|c|c|c|c|c|c|}
\hline \multirow{3}{*}{$\begin{array}{c}\text { Skor } \\
\text { CPITN }\end{array}$} & \multicolumn{4}{|c|}{ Lama merokok (tahun) } & \multirow{2}{*}{\multicolumn{2}{|c|}{ Total }} \\
\hline & \multicolumn{2}{|c|}{$1-10$} & \multicolumn{2}{|c|}{$>10$} & & \\
\hline & $\mathrm{n}$ & $\%$ & $\mathrm{n}$ & $\%$ & $\mathrm{n}$ & $\%$ \\
\hline 0 & 0 & 0 & 0 & 0 & 0 & 0 \\
\hline 1 & 0 & 0 & 0 & 0 & 0 & 0 \\
\hline 2 & 6 & 6,74 & 2 & 2,25 & 8 & 8,99 \\
\hline 3 & 7 & 7,87 & 38 & 42,70 & 45 & 50,56 \\
\hline 4 & 1 & 1,12 & 35 & 39,32 & 36 & 40,45 \\
\hline Total & 14 & 15,73 & 75 & 84,27 & 89 & 100,00 \\
\hline
\end{tabular}

Tabel 5. Distribusi kebutuhan perawatan berdasarkan jumlah rokok

\begin{tabular}{|c|c|c|c|c|c|c|c|c|}
\hline \multirow{3}{*}{$\begin{array}{l}\text { Tipe } \\
\text { Pelayanan }\end{array}$} & \multicolumn{6}{|c|}{ Jumlah rokok (batang/hari) } & \multirow{2}{*}{\multicolumn{2}{|c|}{ Total }} \\
\hline & \multicolumn{2}{|c|}{$<10$} & \multicolumn{2}{|c|}{$10-20$} & \multicolumn{2}{|c|}{$>20$} & & \\
\hline & $\mathrm{n}$ & $\%$ & $\mathrm{n}$ & $\%$ & $\mathrm{n}$ & $\%$ & $\mathrm{n}$ & $\%$ \\
\hline 0 & 0 & 0 & 0 & 0 & 0 & 0 & 0 & 0 \\
\hline I & 0 & 0 & 0 & 0 & 0 & 0 & 0 & 0 \\
\hline II & 5 & 5,62 & 33 & 37,08 & 15 & 16,85 & 53 & 59,55 \\
\hline III & 2 & 2,25 & 19 & 21,35 & 15 & 16,85 & 36 & 40,45 \\
\hline Total & 7 & 7,87 & 52 & 58,43 & 30 & 33,70 & 89 & 100,00 \\
\hline
\end{tabular}


Suhanda, Pangemanan, Juliatri: Gambaran kebutuhan perawatan...

Tabel 6. Distribusi kebutuhan perawatan berdasarkan lama merokok

\begin{tabular}{|c|c|c|c|c|c|c|}
\hline \multirow{3}{*}{$\begin{array}{l}\text { Tipe } \\
\text { Pelayanan }\end{array}$} & \multicolumn{4}{|c|}{ Lama merokok (tahun) } & \multirow{2}{*}{\multicolumn{2}{|c|}{ Total }} \\
\hline & \multicolumn{2}{|c|}{$1-10$} & \multicolumn{2}{|c|}{$>10$} & & \\
\hline & $\mathrm{n}$ & $\%$ & $\mathrm{n}$ & $\%$ & $\mathrm{n}$ & $\%$ \\
\hline 0 & 0 & 0 & 0 & 0 & 0 & 0 \\
\hline I & 0 & 0 & 0 & 0 & 0 & 0 \\
\hline II & 13 & 14,61 & 40 & 44,94 & 53 & 59,55 \\
\hline III & 1 & 1,12 & 35 & 39,33 & 36 & 40,45 \\
\hline Total & 14 & 15,73 & 75 & 84,27 & 89 & 100,00 \\
\hline
\end{tabular}

\section{BAHASAN}

Pengambilan data melalui kuesioner dan pemeriksaan skor CPITN dilakukan di desa Matungkas kecamatan Dimembe dengan jumlah responden sebanyak 89 orang berusia 25-50 tahun. Responden terdiri dari 84 orang $(94,40 \%)$ laki-laki dan 5 orang (5,60\%) perempuan. Responden laki-laki lebih banyak merokok dibandingkan perempuan. Hal ini sesuai dengan teori yang menyatakan bahwa perilaku merokok diterima sebagai bagian perilaku normal bagi laki-laki, bahkan dianggap sebagai simbol kejantanan seperti yang banyak dipromosikan lewat iklaniklan rokok. ${ }^{8,9}$ Kebiasaan merokok pada laki-laki dapat diterima oleh masyarakat Indonesia, dari sisi budaya kebiasaan merokok pada perempuan dianggap sebagai perilaku menyimpang. ${ }^{10}$

Data menunjukkan jumlah perokok paling banyak yaitu berpendidikan terakhir SMA sebanyak 45 responden (50,57\%) dan yang paling sedikit yaitu SD dan S1/PT masing-masing sebanyak 1 responden (1,12\%). Berdasarkan penelitian yang dilakukan oleh Gilman et al., tidak terdapat hubungan antara pendidikan dan kebiasaan merokok dan hal ini sesuai dengan temuan dari Breslau et al. ${ }^{11}$ Data juga menunjukkan responden paling banyak bekerja sebagai petani yaitu sebanyak 25 orang $(28,10 \%)$ dan paling sedikit yaitu tukang kayu dan PNS masing-masing 6 responden (6,70\%). Hasil ini berbeda dengan hasil penelitian dari Kouvonen et al yang menyimpulkan bahwa pekerjaan yang membutuhkan tenaga besar namun berpenghasilan sedikit memiliki hubungan dengan kebiasaan merokok. Peluang menjadi perokok 1,28 kali lebih tinggi pada perempuan dan 1,13

kali lebih tinggi pada laki-laki dengan pekerjaan yang membutuhkan tenaga besar namun berpenghasilan sedikit. ${ }^{12}$

Distribusi kebiasaan merokok menunjukkan sebanyak 52 responden (58,43\%) memiliki kebiasaan merokok 1020 batang/hari, dan sebanyak 75 responden $(84,27 \%)$ sudah merokok selama $>10$ tahun. Umumnya responden mengalami kesulitan untuk berhenti sebagai efek dari kandungan nikotin dalam rokok yang mengakibatkan ketergantungan. Hasil penelitian ini menunjukkan masalah periodontal yang paling banyak terjadi yaitu poket patologis $4-5,5 \mathrm{~mm}$ sebanyak 45 responden $(50,56 \%)$, dan tidak terdapat status periodontal baik dan perdarahan setelah probing. Hasil ini didukung dengan penelitian yang dilakukan oleh Jacob, dkk pada tahun 2008 bahwa penggunaan tembakau mengakibatkan efek yang kronis pada jaringan periodontal dan mengurangi perdarahan setelah probing. ${ }^{13}$

Skor rata-rata CPITN pada setiap sektan menunjukkan besarnya masalah periodontal yang ditemukan. Semakin tinggi skor rata-rata CPITN pada suatu sektan, semakin banyak permasalahan yang ditemukan pada sektan tersebut. Distribusi skor rata-rata CPITN pada setiap sektan diperoleh skor rata-rata tertinggi ialah sektan 4 atau sektan kanan bawah yaitu 2,74, dan yang terendah ialah sektan 2 atau sektan anterior atas yaitu 2,52. Hasil ini hampir sama dengan penelitian yang dilakukan oleh Jogezai, dkk yang 
menunjukkan skor rata-rata tertinggi pada sektan 4 dan terendah pada sektan 1, 2, dan $5 .^{14}$ Skor rata-rata CPITN yang rendah pada sektan 2 dapat disebabkan oleh posisinya yang berada di bagian anterior atas dan mudah dijangkau ketika menyikat gigi, sehingga masalah periodontal yang ditemukan lebih sedikit dibandingkan dengan sektan yang lain. Skor CPITN terbanyak pada sektan 4 yaitu skor 3 yang menggambarkan poket patologis $4-5,5 \mathrm{~mm}$. Terbentuknya poket diakibatkan oleh penumpukan plak dan invasi bakteri plak gigi tersebut.

Status periodontal berdasarkan jumlah rokok terbanyak pada jumlah rokok $<10$ batang/hari yaitu kalkulus sebanyak 4 responden $(4,50 \%)$, terbanyak pada jumlah rokok 10-20 batang/hari yaitu poket patologis 4-5,5mm sebanyak 31 responden (34,83\%), dan terbanyak pada jumlah rokok $>20$ batang/hari yaitu poket patologis $\geq 6 \mathrm{~mm}$ sebanyak 15 responden $(16,85 \%)$. Hasil penelitian memperlihatkan bahwa semakin banyak jumlah rokok yang dikonsumsi per harinya, semakin besar masalah periodontal yang ditemukan. Hal ini dikarenakan beberapa zat kimia dalam rokok yang bersifat kumulatif, sehingga pada saat zat tersebut telah menjadi toksis akan terlihat gejala yang ditimbulkan. ${ }^{15}$

Status periodontal berdasarkan lama merokok menunjukkan poket patologis 4$5,5 \mathrm{~mm}$ paling banyak ditemukan pada perokok dengan lama merokok 1-10 tahun (7 responden/ 7,87\%) dan >10 tahun (38 responden/ 42,70\%). Poket patologis 4$5,5 \mathrm{~mm}$ dapat mengindikasikan adanya periodontitis tahap awal. ${ }^{4}$ Mullaly menyatakan bahwa periodontitis karena merokok dapat terjadi akibat konsumsi rokok dengan dosis yang tinggi dan dalam jangka waktu yang lama. Pada perokok yang mengkonsumsi rokok kurang dari 5 batang per hari dan memiliki kebiasaan merokok kurang dari 3 tahun tidak ditemukan kasus periodontitis. ${ }^{16}$

Kebutuhan perawatan berdasarkan jumlah rokok menunjukkan kategori perokok ringan yang menghisap rokok $<10$ batang/hari paling banyak membutuhkan perawatan dengan tipe pelayanan II yaitu perbaikan OHIS disertai skeling sebanyak 5 responden (5,62\%), kategori perokok sedang yang menghisap rokok 10-20 batang/hari paling banyak membutuhkan perawatan dengan tipe pelayanan II sebanyak 33 responden (37,08\%), dan kategori perokok berat yang menghisap rokok >20 batang/hari membutuhkan perawatan dengan tipe pelayanan II dan III masing-masing 15 responden (16,85\%). Hasil ini didukung dengan penelitian yang dilakukan oleh Alamsyah, dkk yang menunjukkan terdapat hubungan jumlah batang rokok yang dihisap terhadap status periodontal. $^{4}$

Kebutuhan perawatan berdasarkan lama merokok menunjukkan perokok 1-10 tahun yang membutuhkan perawatan dengan tipe pelayanan II sebanyak 13 responden (14,61\%) dan tipe pelayanan III sebanyak 1 responden $(1,12 \%)$. Perokok $>10$ tahun yang membutuhkan perawatan dengan tipe pelayanan II sebanyak 40 responden (44,94\%) dan tipe pelayanan III sebanyak 35 responden (39,33\%). Hasil ini sesuai dengan teori yang menyatakan bahwa pengaruh merokok terhadap jaringan periodontal dapat bervariasi dilihat dari frekuensi paparan tembakau dalam rongga mulut. Pengukuran kedalaman poket yang lebih tinggi ditemukan pada perokok sebagai akibat hilangnya tulang alveolar. ${ }^{17}$ Semakin lama rongga mulut seseorang terpapar tembakau, maka semakin besar pengaruhnya pada rongga mulut dalam hal ini terbentuknya poket patologis $4-5,5 \mathrm{~mm}$. Sebagian besar responden dalam penelitian ini merokok sejak usia muda dan berlangsung sampai bertahun-tahun. Hal ini memperburuk status periodontal, sehingga tidak ditemukan adanya kebutuhan perawatan dengan tipe pelayanan 0 dan I melainkan II dan III yang menunjukkan tidak terdapatnya responden dengan status periodontal sehat dan perdarahan setelah probing. Tipe pelayanan yang paling dibutuhkan yaitu tipe II, sehingga tenaga kesehatan yang paling dibutuhkan dalam populasi ini ialah perawat gigi dan dokter gigi umum. 


\section{SIMPULAN}

Hasil penelitian ini menunjukkan bahwa gambaran kebutuhan perawatan pada perokok di desa Matungkas kecamatan Dimembe yaitu kebutuhan perawatan berdasarkan jumlah rokok dan lama merokok yang paling banyak ditemukan ialah tipe pelayanan II dengan kebutuhan perawatan perbaikan OHIS disertai skeling.

\section{SARAN}

1. Perlu ditingkatkan upaya pencegahan dan perawatan penyakit periodontal oleh tenaga kesehatan.

2. Masyarakat perlu menjaga kebersihan mulutnya dengan cara menyikat gigi dengan waktu dan cara yang benar, pemeriksaan rutin ke dokter gigi setiap 6 bulan sekali, serta mengurangi kebiasaan merokok yang merupakan salah satu faktor penyebab penyakit periodontal.

3. Perlu dilakukan penelitian yang lebih lanjut dengan subjek yang lebih bervariasi untuk melihat hubungan jumlah rokok, dan lama merokok dengan status periodontal serta kebutuhan perawatan.

\section{DAFTAR PUSTAKA}

1. Situmorang N. Dampak Karies Gigi dan Penyakit Periodontal Terhadap Kualitas Hidup. Pidato Pengukuhan Jabatan Guru Besar Tetap. Medan: Universitas Sumatera Utara, 2005; p. 45.

2. Wahyukundari MA. Perbedaan Kadar Matrix Metalloproteinase-8 Setelah Scaling dan Pemberian Tetrasiklin pada Penderita Periodontitis Kronis. Surabaya: Jurnal PDGI;(58):2009. p. 12.

3. Sintawati FX, Tjahja I. Faktor-faktor yang Mempengaruhi Kebersihan Gigi dan Mulut Masyarakat DKI Jakarta Tahun 2007. Jakarta: Jurnal Ekologi Kesehatan;8(1):2008. p. 860.

4. Alamsyah RM. Faktor-Faktor yang Mempengaruhi Kebiasaan Merokok dan Hubungannya dengan Status Penyakit Periodontal Remaja di Kota
Medan Tahun 2007 [Tesis]; 2009.

5. World Health Organization. World Health Statistics. Perancis: WHO Library Cataloguing; 2012. p. 119.

6. World Health Organization. WHO Report on The Global Tobacco Epidemic, 2013 (Country Profile Indonesia). Luxembourg: WHO Library Cataloguing; 2013. p. 1.

7. Badan Penelitian dan Pengembangan Kesehatan. Riset Kesehatan Dasar [Laporan Nasional]. Jakarta: Bakti Husada; 2008. p. 177.

8. $\mathbf{N g} \mathbf{N}$, Weinehall $\mathbf{L}$, Ohman A. 'If I don't smoke, I'm not a real man'-Indonesian Teenage Boys' views about smoking. Health Education Research;2007;22(6): p. 794-804.

9. Nichter M, Padmawati S, Danardono M, Ng N, Prabandari Y, Nichter $M$. Reading Culture From Tobacco Advertisements In Indonesia. Tobacco Control;2009;19: p. 98-107.

10.Barraclough S. Women and Tobacco In Indonesia. Tobacco Control;1999;8: p. 327-32.

11.Gilman SE, Martin LT, Abrams DB, Kawachi I, Kubzansky L, Loucks EB, dkk. Educational Attainment and Cigarette Smoking: A Causal Association?. The International Journal of Epidemiology;2008;37(3): p. 61524.

12.Kouvonen A, Kivimaki M, Virtanen M, Pentti J, Vahtera J. Working Stress, Smoking Status, and Smoking Intensity: An Observational Study of 46190 Employees. J Epidemiol Community Health;2005;59(1): p. 63-9.

13.Jacob V, Vellappally S, Smejkalova J, Rajkumar K, Cermakova E, Fiala Z, dkk. Tobacco Use In Smokeless and Smoking Forms and Its Effect On Periodontal Health In India. Central European Journal of Medicine; 2008;3(1): p. 97-104.

14.Jogezai U, Maxood A, Khan NA. Comparison Of Periodontal Health Status Of Smokers Versus Nonsmokers. J Ayub Med Coll Abbottabad; 2013;25(1-2): p. 183-6.

15.Jode J. Gambaran Kebiasaan Merokok pada Pasien-pasien Hipertensi yang Datang Berobat ke Bagian Penyakit Dalam 
RSUP. H. Adam Malik. [Skripsi] Medan 2010.

16.Mullaly BH. The Influence Of Tobacco Smoking On The Onset of Periodontitis In Young Person. Divisi of Periodontics. Queen's University of Belfast. North Ireland. 2004.

17.Gautam DK, Jindal V, Gupta SC, Tuli A,
Kotwal B, Thakur R. Efek Menghisap Rokok Terhadap Status Kesehatan Periodontal: Sebuah Penelitian Komparatif, Cross-sectional. Siampa F A, trans. India: Journal of Indian Society of Periodontology; 2011;15(4): p. 383-7. 